\title{
Dissolved azaspiracids are absorbed and metabolized by blue mussels (Mytilus edulis)
}

\author{
Thierry Jauffrais $^{\mathrm{a}, \mathrm{c}, *}$, Jane Kilcoyne ${ }^{\mathrm{b}}$, Christine Herrenknecht $^{\mathrm{c}}$, ${\text { Philippe } \text { Truquet }^{\mathrm{a}} \text {, Véronique Séchet }}^{\mathrm{a}}$, \\ Christopher O. Miles ${ }^{d}$, Philipp Hess ${ }^{a, *}$
}

\author{
${ }^{a}$ IFREMER, Laboratoire EMP/PHYC, Rue de l'lle d'Yeu, 44311 Nantes, France \\ ${ }^{\mathrm{b}}$ Marine Institute, Rinville, Oranmore, Co. Galway, Ireland \\ ${ }^{c}$ LUNAM, Université de Nantes, MMS EA2160, Faculté de Pharmacie, 9 rue Bias, 44035 Nantes, France \\ d Norwegian Veterinary Institute, P. O. Box 750 Sentrum, 0106 Oslo, Norway
*: Corresponding authors : Thierry Jauffrais, email address : thierry.jauffrais@ifremer.fr ; Philippe Hess, email address : philipp.hess@ifremer.fr

\begin{abstract}
:
The relationship between azaspiracid shellfish poisoning and a small dinoflagellate, Azadinium spinosum, has been shown recently. The organism produces AZA1 and -2, while AZA3 and other analogues are metabolic products formed in shellfish. We evaluated whether mussels were capable of accumulating dissolved AZA1 and -2 , and compared the toxin profiles of these mussels at $24 \mathrm{~h}$ with profiles of those exposed to live or lysed $A$. spinosum. We also assessed the possibility of preparative production of AZA metabolites by exposing mussels to semi-purified AZA1.
\end{abstract}

We exposed mussels to similar concentration of AZAs: dissolved AZA1 + 2 (crude extract) at 7.5 and $0.75 \mu \mathrm{g} \mathrm{L}^{-1}$, dissolved AZA1+2 $\left(7.5 \mu \mathrm{g} \mathrm{L}^{-1}\right)$ in combination with Isochrysis affinis galbana, and lysed and live $A$. spinosum cells at $1 \times 10^{5}$ and $1 \times 10^{4}$ cell mL $\mathrm{m}^{-1}$ (containing equivalent amounts of AZA1 + 2). Subsequently, we dissected and analysed digestive glands, gills and remaining flesh. Mussels (whole flesh) accumulated AZAs to levels above the regulatory limit, except at the lower levels of dissolved AZAs. The toxin profile of the mussels varied significantly with treatment. The gills contained $42-46 \%$ and the digestive glands $23-24 \%$ of the total toxin load using dissolved AZAs, compared to $3-12 \%$ and $75-90 \%$, respectively, in mussels exposed to live $A$. spinosum. Exposure of mussels to semi-purified AZA1 produced the metabolites AZA17 (16.5\%) and AZA3 (1.7\%) after 4 days of exposure, but the conversion efficiency was too low to justify using this procedure for preparative isolation.

\section{Highlights}

Blue mussels were exposed to dissolved AZAs, live and lysed Azadinium spinosum. Mussels accumulated dissolved AZAs to greater than legal limit. Biotransformation of algal toxins into shellfish metabolites was observed. Mussels accumulate AZAs mainly in gills when AZAs are dissolved. Mussels accumulate AZAs mainly in digestive glands when fed $A$. spinosum.

Keywords: Dissolved marine biotoxins ; AZA ; Tissue distribution ; Bivalve molluscs ; LC-MS/MS ; Azaspiracid 


\section{Introduction}

Azaspiracid shellfish poisoning (AZP) occurred for the first time in the Netherlands in November 1995. Contaminated mussels (Mytilus edulis) cultivated in Ireland (Killary Harbour) were consumed and intoxicated at least eight people (McMahon and Silke, 1996). Three years later the implicated toxin was identified, isolated, structurally defined and named azaspiracid (now called azaspiracid-1 (AZA1)) due to its unique spiro ring assembly (Satake et al., 1998). The structure has since been corrected following its chemical synthesis (Nicolaou et al., 2006).

AZAs have been found in aquatic organisms in Europe, Africa and more recently in the Americas and Japan (Alvarez et al., 2010; Amzil et al., 2008; Furey et al., 2010; Klontz et al., 2009; Magdalena et al., 2003; Taleb et al., 2006; Twiner et al., 2008; Ueoka et al., 2009), indicating a worldwide phenomenon. More than 30 AZA analogs have been reported (Rehmann et al., 2008). Of these, only AZA1 and -2 were actually found in the primary producer (Krock et al., 2009) recently isolated and named $A$. spinosum (Krock et al., 2008; Krock et al., 2009; Tillmann et al., 2009). A. spinosum is a small dinoflagellate (12-16 $\mu \mathrm{m}$ length and 7-11 $\mu \mathrm{m}$ width), originally isolated in the North Sea near the Scottish coast (Tillmann et al., 2009). Following its description, another $A$. spinosum was isolated in Ireland (Salas et al., 2011), and Azadinium obesum (not known to produce AZAs, North Sea) (Tillmann et al., 2010), and Azadinium poporum (North Sea) and Azadinium cf. poporum (Korean coast) (Potvin et al., 2012; Tillmann et al., 2011) were isolated and characterised. The last two species were recently found to produce new AZAs, also observed in Amphidoma languida, a species close to Azadinium spp. in terms of phylogeny (Krock et al., 2012; Tillmann et al., 2012). A. cf. spinosum has been observed and described in Argentina, where the authors reported a bloom $\left(9 \times 10^{6}\right.$ cells $\left.\mathrm{L}^{-1}\right)$ in 1990 , although no data on AZAs or reports of intoxications were reported (Akselman and Negri, 2012).

Since its discovery, the North Sea strain of $A$. spinosum has been cultured for toxin production in pilot-scale photobioreactors (Jauffrais et al., 2012b). However, while the organism produces AZA1 and -2 , it does not produce the metabolites formed in shellfish (AZA3 to -23, reviewed in Rehmann et al. (2008)) (Krock et al., 2009; McCarron et al., 2009). The first demonstration of AZA accumulation in mussels after controlled exposure to $A$. spinosum showed rapid biotransformation of AZA1 to AZA17 (Salas et al., 2011). This fast biotransformation was subsequently confirmed in a larger scale experiment, where AZA17 and -19 were identified as major metabolites that should be regulated in uncooked mussels (Jauffrais et al., 2012c), as during cooking, AZA17 and -19 are biotransformed into AZA3 and -6 , respectively (McCarron et al., 2009); two AZAs known to be toxic. AZA3 has an AZA1 toxic equivalent factor (TEF) of 1.4 (Ofuji et al., 1999) and concerning the relative in vitro potency of AZA6, it appears to be not unlike that of AZA1 (Dr. M. Twiner, personal communication). No purified AZA17 and -19 are currently available for use as analytical standards, however, nor is there a sustainable way of producing AZA3, an already regulated degradation product of AZA17, other than by complex organic synthesis (Perez et al., 2010) or isolation from contaminated mussels (Kilcoyne et al., 2012; Perez et al., 2010).

A major ecological question is also the bioavailability of dissolved marine biotoxins to marine organisms. Effectively, when harmful algal blooms degrade, they release toxins into the dissolved phase (surrounding water). Studies have been carried out to evaluate toxin accumulation or effects of dissolved toxins on early stages of development of aquatic organisms (Colman et al., 2005; Korpinen et al., 2006; Lefebvre et al., 2005; Liu et al., 2007) on planktonic species (Babica et al., 2007; Bargu et al., 2006) and on adult fish (Bakke and Horsberg, 2010; Cazenave et al., 2005). However, very little is known about the ability of bivalve molluscs to accumulate dissolved marine biotoxins (Liu et al., 2007; Novaczek et al., 1991; Plakas et al., 2002). 
Dissolved AZAs, found in waters on the Irish and Norwegian coasts, raises questions on the ability of mussels to accumulate dissolved AZAs in situ (Fux et al., 2009; Rundberget et al., 2009). Transplanted mussels (free of AZAs) followed the same kinetics of uptake as SPATT (solid phase adsorption toxin tracking) discs, but concurrent contamination through dissolved AZAs and by $A$. spinosum cells cannot be excluded in that field study (Fux et al., 2009). Furthermore, a recent study (O'Driscoll et al., 2011) on AZA1 biotransformation by mussels showed the ability of mussels to accumulate dissolved AZA1 when co-administered with a commercial bivalve. However, the authors only focused on biotransformation pathways and did not quantify the concentrations of AZAs accumulated in the mussel tissues.

The present study explored the ability of mussels to accumulate dissolved AZAs and the effect of route of administration on toxin profiles site of AZAs accumulation in mussels. A second trial was performed to assess whether this procedure could be used for preparative isolation of metabolites when mussels were also exposed to a high concentration of dissolved purified AZA1.

\section{Material and methods}

\subsection{Collection and maintenance of bivalves}

Trial A. Blue mussels were collected from the West coast of France (Ré Island) in April 2012, a place at that time known to be free of known marine phycotoxins. Mussels were transported to the aquarium facilities, washed, and cleaned of remaining epibionts. They were placed in two $20 \mathrm{~L}$ aerated aquaria, filled with sea water ( $35 \mathrm{psu}$ ) and maintained at \pm 16 ${ }^{\circ} \mathrm{C}$ (room temperature). The mussels were unfed for 5 days prior to the experiment to clean their digestive tract of all lingering food. Their average length $(44 \pm 3 \mathrm{~mm})$ was above commercial size, with a wet-flesh weight of $1.9 \pm 0.2 \mathrm{~g}$. Digestive glands accounted for $25.5 \%$, gills $11.7 \%$ and remaining flesh $62.8 \%$ of the total mussel weight.

Trial B. Blue mussels were obtained from Kelly Shellfish, Kilcolgan, Ireland, in November 2011, at that time known to be free of known marine phycotoxins. They were washed, cleaned of remaining epibionts, and placed in $10 \mathrm{~L}$ aquaria containing filtered $(0.2 \mu \mathrm{m})$ and aerated seawater. Mussels were above commercial size, sea water was changed daily, and mussels were fed a commercial diet for bivalves containing Isochrysis, Pavlova, Tetraselmis and Thalassiosira weissflogii (Shellfish diet 1800, Reed Mariculture, Cambell, USA).

\subsection{Phytoplankton}

A. spinosum strain 3D9 was used to study accumulation of AZA1 and -2 in mussels. The alga was grown in a stirred photobioreactor $(100 \mathrm{~L})$ operated in chemostat mode at a dilution rate of 0.2 day $^{-1}$ under the environmental conditions of Jauffrais et al. (2012b).

Isochrysis aff. galbana (CCAP 927/14, T-Iso) was grown in $10 \mathrm{~L}$ batch culture under the same conditions as for $A$. spinosum, but in F/2 medium (Guillard, 1975; Guillard and Ryther, 1962). Cell concentrations (cell. $\mathrm{mL}^{-1}$ ) were determined using a particle counter (Multisizer 3 Coulter counter, Beckman) and assessed 6 times in the different conditions using $A$. spinosum and T-Iso.

\subsection{Preparation of crude and semi-purified toxin extracts}

Crude extract of $A$. spinosum was used as dissolved AZA1 and -2. A $200 \mathrm{~L}$ culture of $A$. spinosum was maintained in an aerated $300 \mathrm{~L}$ transparent cylindroconical tank after production in two $100 \mathrm{~L}$ stirred photobioreactors at a flow rate of 0.2 day $^{-1}$. Biomass $(200 \mathrm{~L})$ 
was collected by tangential flow filtration, followed by adsorption of AZAs onto activated HP20 Diaion resin $(25 \mathrm{~g})$ from the sonicated algal concentrate $( \pm 1 \mathrm{~L})$. The washed resin was placed in a glass column and eluted with acetone $(3 \times 50 \mathrm{~mL})$, and the eluate evaporated and reconstituted in $10 \mathrm{~mL}$ of methanol (Jauffrais et al., 2012b). This crude algal extract contained $110 \pm 6 \mu \mathrm{g} \cdot \mathrm{mL}^{-1}$ of AZA1 plus AZA2 (ratio 79:21). Aliquots (541 or $54 \mu \mathrm{L}$ ) of this solution were added to $8 \mathrm{~L}$ of sea water in trial $A$.

Semi-purified AZA1 was obtained from mussel tissue ( $M$. edulis) collected in 2005 from Bruckless, Donegal, Ireland following the $6^{\text {th }}$ step of a 7 step isolation procedure as described in Kilcoyne et al. (2012), and used in trial B.

\subsection{Experimental design}

Trial $A$. After acclimatisation to the laboratory conditions, 120 mussels were distributed in $10 \mathrm{~L}$ aerated flat-bottomed glass flasks (5 per flask) with $8 \mathrm{~L}$ of sea water. Each treatment was performed in triplicate and the mussels were exposed to the conditions presented in table 1.

Aliquots (541 or $54 \mu \mathrm{L}$ ) of crude extract were added to $8 \mathrm{~L}$ of sea water with (treatement 1 and 2 ) or without T-Iso (treatement 3 ) and live and lysed $A$. spinosum cells were obtained from a culture $\left(2.15 \times 10^{5} \pm 3 \times 10^{3}\right.$ cell $\left.\mathrm{mL}^{-1}\right)$ in a bioreactor at steady state with a cell quota of $75.4 \pm 0.8$ fg.cell $^{-1}$ AZA1 plus AZA2 (ratio 76:24). The required concentrations were obtained by dilution with sea water (treatement 4 and 6 ). For treatments 5 and 7 , the culture $(A$. spinosum) was sonicated (pulse mode, $30 \mathrm{~min}$ in ice, maximum amplitude, Bioblock Scientific, Vibra-cell 75115), and a sample was checked to ensure total cellular lysis.

Trial B: Acclimatized mussels (3) were transferred to a $5 \mathrm{~L}$ conical flask containing $3 \mathrm{~L}$ of filtered seawater, to which Shellfish diet $1800(100 \mu \mathrm{L})$ and $100 \mu \mathrm{L}$ of semi-purified AZA1 solution were added, to give a final AZA1 concentration of $33 \mu \mathrm{g} \mathrm{L}^{-1}$.

\subsection{AZA analysis}

\subsubsection{Reagents}

Certified reference materials (CRMs) of AZA1, -2 and -3 were from the NRC, Certified Reference Material Program (Halifax, NS, Canada). Ammonium formate (reagent grade) and formic acid were from Sigma-Aldrich (Steinheim, Germany).

Trial A: Acetone and methanol (HPLC grade) were from JT Baker. Milli-Q water for the HPLC mobile phase was supplied by a Milli-Q integral 3 system (Millipore).

Trial B: All solvents (pestican grade) were from Labscan (Dublin, Ireland).

\subsubsection{AZA extraction from $A$. spinosum}

Triplicate samples of $A$. spinosum culture were taken from the harvesting tank prior to mussel exposure and extracted according to Jauffrais et al. (2012a). Briefly, aliquots $(10 \mathrm{~mL})$ of $A$. spinosum cultures were collected and centrifuged $\left(2500 \mathrm{~g}, 4{ }^{\circ} \mathrm{C}, 20 \mathrm{~min}\right)$. The pellet was re-suspended in acetone- $\mathrm{H}_{2} \mathrm{O}(0.5 \mathrm{~mL}, 9: 1, \mathrm{v} / \mathrm{v})$, transferred to an Eppendorf tube, sonicated and centrifuged. The supernatant was transferred to a $5 \mathrm{~mL}$ glass tube and gently evaporated under nitrogen $\left(35^{\circ} \mathrm{C}\right)$. The pellet was re-extracted twice more in the same manner. the combined extracts evaporated, and the residue reconstituted in methanol (1 $\mathrm{mL})$, filtered, and analyzed by LC-MS/MS (method A). 


\subsubsection{AZA extraction from Mussel tissues}

Trial A: The extraction procedure was adapted from Villar-Gonzalez et al. (2011) as detailed in Jauffrais et al. (2012c). At the end of the exposure, mussels were opened to allow mantle fluid to drain, gills were carefully dissected with scissors, the digestive gland was separated from the mussel tissues, and the remaining flesh was detached from the shell. The 3 different tissues from the five mussels of each flask were drained for 5 min, placed in a $50 \mathrm{~mL}$ centrifuge tube and weighed to measure wet weight, then stored at $-80^{\circ} \mathrm{C}$ until extraction.

Prior to extraction, the tissues were thawed, methanol $(9 \mathrm{~mL})$ was added, and samples were extracted using a high-speed homogenizer (Polytron PT1300D) at $15000 \mathrm{rpm}$ for $5 \mathrm{~min}$. Samples were centrifuged at $4500 \mathrm{~g}$ for $5 \mathrm{~min}$ at $4{ }^{\circ} \mathrm{C}$, and the supernatants transferred to $20 \mathrm{~mL}$ volumetric flasks. Another $9 \mathrm{~mL}$ of methanol was added to the remaining pellet and homogenized again. Centrifugation was repeated as above, and supernatants were transferred to the same $20 \mathrm{~mL}$ volumetric flasks. Volumetric flasks were then made up to the mark using methanol, extracts were filtered (Nonosep MF $0.2 \mu \mathrm{m}$ centrifugal filter), and analyzed by LC-MS/MS (method A).

Trial B: After exposure, mussels were removed from the tank, opened to allow mantle fluid to drain, shucked and weighed. The mussel tissue was transferred to a Waring blender and homogenized for $1 \mathrm{~min}$. Homogenized tissue $(1.0 \mathrm{~g})$ was extracted twice (Ultra turrax, IKAWerke T25 at $11000 \mathrm{rpm})$ for $1 \mathrm{~min}$ with methanol $(2 \times 9 \mathrm{~mL})$. Extracts were centrifuged (3 $950 \mathrm{~g}, 5 \mathrm{~min}$ ) and the supernatants decanted into $25 \mathrm{~mL}$ volumetric flasks which were brought to volume with methanol. Samples were filtered (Millipore PVDF, $0.45 \mu \mathrm{m}$ ) prior to analysis by LC-MS/MS (method B).

\subsubsection{AZA extraction from sea water}

Solid phase extraction (SPE) cartridges (Oasis HLB, $3 \mathrm{cc}, 100 \mathrm{mg}$ ) were activated with methanol $(5 \mathrm{~mL})$ and washed with a solution of water-methanol $(9: 1 \mathrm{v} / \mathrm{v}, 3 \mathrm{~mL})$. The sample $(5 \mathrm{~mL})$ was then loaded dropwise, the cartridge washed with water-methanol $(9: 1 \mathrm{v} / \mathrm{v}, 5 \mathrm{~mL})$, and the sample eluted with methanol $(5 \mathrm{~mL})$ into a glass tube for analysis by LC-MS/MS (method B) (Kilcoyne et al., 2012).

\subsubsection{LC-MS/MS analysis}

Method A: The samples were analyzed by LC-MS/MS to quantify AZAs using an HPLC (model UFLCxr, Shimadzu) coupled to a triple-quadrupole mass spectrometer (API 4000Qtrap, Applied Biosystems). Separation and LC-MS/MS procedures were as described by Jauffrais et al. (2012c) and based on a previous study (Rehmann et al., 2008). External calibration against AZA1, -2 and -3 were used for quantification using Analyst 1.5 software (Applied Biosystems), assuming that all analogues had the same response factor as AZA1, except for AZA2 and -3 for which the respective standards were used.

Toxic Equivalent Factors (TEFs) were also applied to estimate the true toxic potential of mussel samples during the experiment. AZA1 TEFs applied were equal to 1.8 and 1.4 for AZA2 and -3 , respectively (Ofuji et al., 1999).

Method B: Samples were analyzed on a Waters 2695 LC coupled to a Micromass triplestage quadrupole Ultima instrument operated in multiple reaction monitoring (MRM) mode with the following transitions: AZA1, $\mathrm{m} / \mathrm{z} \quad 842.5 \rightarrow 654.4$ and $842.5 \rightarrow 672.4$; AZA3, $828.5 \rightarrow 640.4$ and $828.5 \rightarrow 658.4$; AZA17, $872.5 \rightarrow 640.5$ and $872.5 \rightarrow 658.4$. The cone voltage 
was $60 \mathrm{~V}$ and the collision voltage was $40 \mathrm{~V}$, the cone and desolvation gas flows were set at 100 and $800 \mathrm{~L} / \mathrm{h}$, respectively, and the source temperature was $150{ }^{\circ} \mathrm{C}$.

Binary gradient elution was used, with phase A consisting of water and phase B of $95 \%$ acetonitrile in water (both containing $2 \mathrm{mM}$ ammonium formate and $50 \mathrm{mM}$ formic acid). Chromatography was performed with a Hypersil BDS C8 column $(50 \times 2.1 \mathrm{~mm}, 3 \mu \mathrm{m}$, with a $10 \times 2.1 \mathrm{~mm}$ guard column of the same stationary phase) (Thermo Scientific). The gradient was from $30 \%$ B to $90 \%$ B over 8 min at $0.25 \mathrm{~mL} \mathrm{~min}^{-1}$, held for $5 \mathrm{~min}$, then held at $100 \% \mathrm{~B}$ at $0.4 \mathrm{~mL} \cdot \mathrm{min}^{-1}$ for $5 \mathrm{~min}$, before returning to the initial conditions (4 min hold) to equilibrate the system. The injection volume was $5 \mu \mathrm{L}$ and the column and sample temperatures were $25^{\circ} \mathrm{C}$ and $6{ }^{\circ} \mathrm{C}$, respectively.

\section{Results and discussion}

Dissolved AZAs as well as other lipophilic toxins were found in water using passive samplers on the west coast of Ireland (Fux et al., 2009). This raised questions on the bioavailability of dissolved AZAs to shellfish or other aquatic organisms, especially, since other dissolved polyether marine biotoxins have been found to accumulate in shellfish (brevetoxin in Crassostrea virginica (Plakas et al., 2002)). Unfortunately, the passive sampling method used in the first study (Fux et al., 2009) was qualitative and could not estimate actual AZA concentrations in sea water. In the present study two levels of cellular concentrations were investigated. These conditions would correspond to a bloom of $1 \times 10^{5} \mathrm{cell} \mathrm{mL}^{-1}$ of $A$. spinosum and a more realistic scenario of a bloom of $1 \times 10^{4}$ cell $\mathrm{mL}^{-1}$ of $A$. spinosum, similar to that reported in Argentina (Akselman and Negri, 2012). However, to our knowledge, no data are available on the AZA cell quota of $A$. spinosum in natural blooms. We therefore based these experiments on a AZA cell quota obtained from $A$. spinosum in culture, even though these results are only indicative. Subsequently, the first trial evaluated where AZA uptake or accumulation occur, and whether dissolved AZAs released from decaying blooms of $A$. spinosum could be relevant to the shellfish industry and to human health or could play a role in ecological interactions with other aquatic organisms. Thus, AZA accumulation by mussels was assessed using exposure to $A$. spinosum cells (live or lysed), and to dissolved AZAs (alone or in mixture with non-toxic microalgae) as possible routes of contamination.

In treatments 1-7, LC-MS/MS analyses showed the presence of AZAs in the digestive gland, gills and remaining flesh of mussels after $24 \mathrm{~h}$ of exposure (Table 2). Treatments 1 and 3-7 resulted in concentrations of regulated AZAs (255-591 $\mathrm{\mu g} \mathrm{kg}^{-1} \mathrm{AZA1}$ eq) above the regulatory limit (160 $\mathrm{g} \mathrm{kg}^{-1} \mathrm{AZA1}$ eq), treatment 2 (dissolved AZAs at $0.75 \mu \mathrm{g} \mathrm{L}^{-1}$ ) resulted in a total $A Z A$ concentration of $71 \mathrm{\mu g} \mathrm{kg}^{-1} A Z A 1$ eq. These results indicate that AZA accumulation in mussels can occur not only from exposure to living A. spinosum cells (Jauffrais et al., 2012c; Salas et al., 2011), but also from exposure to dissolved AZAs in the presence or absence of algal cells or cellular debris. To our knowledge, this study is the first experiment to quantitatively assess the direct accumulation of dissolved AZAs by mussels without any source of food.

The highest concentrations in mussels were obtained for treatments with the highest concentration of AZAs $\left(7.5 \mu \mathrm{g} \mathrm{L}^{-1}\right)$. Exposure to live $A$. spinosum resulted in higher total AZA accumulation (694 and $464 \mathrm{\mu g} \mathrm{kg}^{-1}$ at $1 \times 10^{5}$ and $1 \times 10^{4}$ cell mL $\mathrm{m}^{-1}$, respectively) than by other routes of exposure to equivalent AZA concentrations (Table 2).

Interestingly, at the higher Azadinium concentration, mussels consumed only $20 \%$ of the live A. spinosum cells $\left(1 \times 10^{5} \mathrm{cell} \mathrm{mL}^{-1}\right)$ over $24 \mathrm{~h}$, whereas at the lower concentration $\left(1 \times 10^{4}\right.$ cell $\left.\mathrm{mL}^{-1}\right)$, all cells were consumed in less than $5 \mathrm{~h}$. Furthermore, mussels exposed to dissolved AZAs with T-Iso consumed $3 / 4$ of the available alga (Fig. 1). Note that Isochrysis 
aff. galbana (CCAP 927/14, T-Iso) is a non-toxic microalga used in aquaculture to feed farmed bivalve molluscs (Marchetti et al., 2012).

Differences in toxin distribution across tissues were observed due to the route of exposure and only minor effects due to toxin level (Fig. 2). When AZAs were dissolved, most of the toxin was found in gills (42-46\%) and remaining flesh $(30-35 \%)$, whereas the toxin was mainly found in the digestive gland when $A$. spinosum cells (either lysed or alive) were the source of the toxin (Fig. 2). The AZA distribution in mussels fed live $A$. spinosum here was similar to that reported in a previous similar experiment $(73 \%$ DG, $8 \%$ gills and $19 \%$ RF (Jauffrais et al., 2012c)). In treatment 3, with dissolved AZA plus non-toxic food, a 2-fold higher concentration of AZA was observed in the digestive gland, compared to treatment 1 (without algae), even though the total amount accumulated into mussel tissues was virtually identical (Table 2). The same trend is observed when examining the percentages of toxin accumulated in digestive gland compared to other tissues, with live $A$. spinosum cells $>$ lysed cells $>$ dissolved plus non-toxic cells $>$ dissolved toxins. Partial adsorption of dissolved AZAs onto the algal cells and cellular debris, followed by ingestion by the mussels, may be responsible for this phenomenon.

In addition to the digestive uptake route previously shown (Jauffrais et al., 2012c; Salas et al., 2011), uptake from the dissolved phase through the gills is a plausible route of accumulation. Similar observations have also been made with fish exposed to water soluble toxins microcystin-RR (Cazenave et al., 2005) and saxitoxin (Bakke and Horsberg, 2010) but to our knowledge no results on accumulation by the gills are reported using only dissolved lipophilic toxins. Furthermore, analogue ratios found in the present study suggest that AZA transformations in gills are faster than in the digestive gland (Table 2 and Fig. 3). However, no data is available on transfer of AZAs across mussel tissues. Consequently, further studies using different organisms, e.g. fish, could help to confirm whether AZA uptake through the gills during ventilation and filtration processes leads to systemic distribution of AZAs.

A similar experiment was performed to study AZA biotransformation in mussels, however, mussels were exposed to dissolved AZAs in combination with a non-toxic microalgal diet (O'Driscoll et al., 2011). These authors observed larger AZA accumulation in gills and remaining tissues than in digestive glands; however, it is difficult to compare further due to the absence of quantitative data and differences in experimental design. Also, these authors found an unusual toxin profile (i.e. a large amount of AZA3), compared to the literature (Fux et al., 2009; Jauffrais et al., 2012c; McCarron et al., 2009; Salas et al., 2011). In most cases, toxin profiles found in the present experiment contained AZA1-3, AZA7, 8, -17 and -19 (Table 2, Fig. 4), and for all tissues AZA3, $-7,-8$ and -19 represented less than $20 \%$ of the total AZAs.

The toxin profile was also found to be different in different mussel organs (table 2 and Fig. 3). For all treatments, the digestive gland always had AZA1 and -2 as the major AZAs (together $>75 \%$ ), whereas in the gills and remaining flesh the main AZAs were AZA1 and -17 , with the proportion of AZA17 often greater than or comparable to that of AZA1 (Fig. 3). Furthermore, the gills and the remaining flesh always showed a higher proportion of metabolites of AZA1 and -2 than the digestive glands. This is in accord with previous results from mussels fed $A$. spinosum (Jauffrais et al., 2012c), and raised questions about the role of the different mussel tissues in AZA biotransformation.

The second objective was to evaluate the feasibility of preparative production of $A Z A$ metabolites using mussels exposed to dissolved semi-purified AZA1. The AZA mass balance of this experiment (Table 3 ) showed an overall AZA recovery of $60 \%$, with AZA1 accounting for $37 \%$, AZA17 for $19 \%$ and AZA3 for $4 \%$. AZAs found in mussels after four days of exposure to AZA1 represented $29 \%$ of the administered toxin, with AZA17 comprising the biggest proportion. Only $17 \%$ of the original AZA1 sample was converted to AZA17 which, 
combined with the fact that the mussels have a limited ability to accumulate AZAs under such conditions, would render this impractical as a means of producing sufficiently contaminated material for isolation purposes. Additionally, a significant proportion $(40 \%)$ of toxin was not accounted for, suggesting additional, unknown, transformation processes occurring within shellfish or in seawater. After 4 days of exposure, low levels $(\sim 2 \%$ of the original AZA1 added to the tank) of both AZA17 and AZA3 were detectable in the seawater, suggesting that these toxins can be excreted by the shellfish, and transported into the surrounding aqueous environments.

\section{Conclusions}

The present study shows that dissolved AZAs were bioavailable for mussels and that AZA accumulation may reach concentrations above the regulatory limit and thus might be considered as a food safety issue. However, differences observed in the distribution of toxins in the shellfish depended on whether the shellfish were exposed to dissolved AZAs or to live or lysed $A$. spinosum. This finding tended to decrease the importance of dissolved AZAs as a source of contamination relevant for human health as the AZA distribution found in situ reflect results observed with live $A$. spinosum. This different AZA distribution between tissues indicates that AZA uptake can occur in the digestive gland during feeding and also through the gills during respiratory and filtration activities in the presence of dissolved AZAs. This last observation raises questions as to the mechanisms involved in the uptake of AZAs through the gills and about the potential for subsequent re-distribution to other organs. The bioavailability of dissolved AZAs shown for mussels also raises questions regards possible effects on other aquatic organisms. The second trial on the preparative production of AZA metabolites by mussel exposure to semi-purified AZA1 resulted in formation of AZA1 metabolites in mussels, but the conversion efficiency and the recovery was too low to justify using this procedure for preparative isolation. Hence, further studies should investigate these losses and the existence of unknown metabolic transformations in mussel and seawater.

\section{Acknowledgment}

This project, ASTOX2 (Grant-Aid Agreement No. PBA/AF/08/001), was carried out under the Sea Change strategy with the support of the Marine Institute and the Marine Research Subprogramme of the National Development Plan 2007-2013, co-financed under the European Regional Development Fund. Further funding was obtained through Ifremer from the French Ministry of Education, Research and Technology through Programme 187 of the National Finance Law. The authors would also like to thank all the members of the laboratory EMP/PHYC at the Atlantic Centre of Ifremer for their help and technical advice during this study and Dr Patrick Lassus for the valuable discussions.

\section{References}

Akselman, R., Negri, R.M., 2012. Blooms of Azadinium cf. spinosum Elbrächter et Tillmann (Dinophyceae) in northern shelf waters of Argentina, southwestern Atlantic. Harmful Algae 19, 30-38.

Alvarez, G., Uribe, E., Avalos, P., Marino, C., Blanco, J., 2010. First identification of azaspiracid and spirolides in Mesodesma donacium and Mulinia edulis from northern Chile. Toxicon 55, 638-641.

Amzil, Z., Sibat, M., Royer, F., Savar, V., 2008. First report on azaspiracid and yessotoxin groups detection in French shellfish. Toxicon 52, 39-48. 
Babica, P., Hilscherova, K., Bartova, K., Blaha, L., Marsalek, B., 2007. Effects of dissolved microcystins on growth of planktonic photoautotrophs. Phycologia 46, 137-142.

Bakke, M.J., Horsberg, T.E., 2010. Kinetic properties of saxitoxin in Atlantic salmon (Salmo salar) and Atlantic cod (Gadus morhua). Comp. Biochem. Physiol. C: Toxicol. Pharmacol. 152, 444-450.

Bargu, S., Lefebvre, K., Silver, M.W., 2006. Effect of dissolved domoic acid on the grazing rate of krill Euphausia pacifica. Mar. Ecol. Prog. Ser. 312, 169-175.

Cazenave, J., Wunderlin, D.A., Bistoni, M.D.L., Ame, M.V., Krause, E., Pflugmacher, S., Wiegand, C., 2005. Uptake, tissue distribution and accumulation of microcystin-RR in Corydoras paleatus, Jenynsia multidentata and Odontesthes bonariensis - a field and laboratory study. Aquat. Toxicol. 75, 178-190.

Colman, J.R., Twiner, M.J., Hess, P., McMahon, T., Satake, M., Yasumoto, T., Doucette, G.J., Ramsdell, J.S., 2005. Teratogenic effects of azaspiracid-1 identified by microinjection of Japanese medaka (Oryzias latipes) embryos. Toxicon 45, 881-890.

Furey, A., O'Doherty, S., O'Callaghan, K., Lehane, M., James, K.J., 2010. Azaspiracid poisoning (AZP) toxins in shellfish: toxicological and health considerations. Toxicon 56, 173-190.

Fux, E., Bire, R., Hess, P., 2009. Comparative accumulation and composition of lipophilic marine biotoxins in passive samplers and in mussels ( $M$. edulis) on the west coast of Ireland. Harmful Algae 8, 523-537.

Guillard, R.R.L., 1975. Culture of phytoplankton for feeding marine invertebrates, in: Smith, W.L., Chanley, M.H. (Eds.), Culture of Marine Invertebrate Animals. Plenum Press, New York, USA, pp. 26-60.

Guillard, R.R.L., Ryther, J.H., 1962. Studies of marine planktonic diatoms. I. Cyclotella nana Hustedt and Detonula confervacea Cleve. Can. J. Microbiol. 8, 229-239.

Jauffrais, T., Herrenknecht, C., Séchet, V., Sibat, M., Tillmann, U., Krock, B., Kilcoyne, J., Miles, C.O., McCarron, P., Amzil, Z., Hess, P., 2012a. Quantitative analysis of azaspiracids in Azadinium spinosum cultures. Anal. Bioanal. Chem. 403, 833-846.

Jauffrais, T., Kilcoyne, J., Sechet, V., Herrenknecht, C., Truquet, P., Herve, F., Berard, J.B., Nulty, C., Taylor, S., Tillmann, U., Miles, C.O., Hess, P., 2012b. Production and isolation of azaspiracid-1 and -2 from Azadinium spinosum culture in pilot scale photobioreactors. Mar. Drugs 10, 1360-1382.

Jauffrais, T., Marcaillou, C., Herrenknecht, C., Truquet, P., Séchet, V., Nicolau, E., Tillmann, U., Hess, P., 2012c. Azaspiracid accumulation, detoxification and biotransformation in blue mussels (Mytilus edulis) experimentally fed Azadinium spinosum. Toxicon 60, 582-595.

Kilcoyne, J., Keogh, A., Clancy, G., Leblanc, P., Burton, I., Quilliam, M.A., Hess, P., Miles, C.O., 2012. Improved isolation procedure for azaspiracids from shellfish, structural elucidation of azaspiracid-6, and stability studies. J. Agric. Food. Chem. 60, 24472455.

Klontz, K.C., Abraham, A., Plakas, S.M., Dickey, R.W., 2009. Mussel-associated azaspiracid intoxication in the United States. Ann. Intern. Med. 150, 361.

Korpinen, S., Karjalainen, M., Viitasalo, M., 2006. Effects of cyanobacteria on survival and reproduction of the littoral crustacean Gammarus zaddachi (Amphipoda). Hydrobiologia 559, 285-295.

Krock, B., Tillmann, U., John, U., Cembella, A., 2008. LC-MS-MS aboard ship: tandem mass spectrometry in the search for phycotoxins and novel toxigenic plankton from the North Sea. Anal. Bioanal. Chem. 392, 797-803.

Krock, B., Tillmann, U., John, U., Cembella, A.D., 2009. Characterization of azaspiracids in plankton size-fractions and isolation of an azaspiracid-producing dinoflagellate from the North Sea. Harmful Algae 8, 254-263.

Krock, B., Tillmann, U., Voß, D., Koch, B.P., Salas, R., Witt, M., Potvin, É., Jeong, H.J., 2012. New azaspiracids in Amphidomataceae (Dinophyceae). Toxicon 60, 830-839. 
Lefebvre, K.A., Elder, N.E., Hershberger, P.K., Trainer, V.L., Stehr, C.M., Scholz, N.L., 2005. Dissolved saxitoxin causes transient inhibition of sensorimotor function in larval Pacific herring (Clupea harengus pallasi). Mar. Biol. 147, 1393-1402.

Liu, H., Kelly, M.S., Campbell, D.A., Dong, S.L., Zhu, J.X., Wang, S.F., 2007. Exposure to domoic acid affects larval development of king scallop Pecten maximus (Linnaeus, 1758). Aquat. Toxicol. 81, 152-158.

Magdalena, A.B., Lehane, M., Krys, S., Fernandez, M.L., Furey, A., James, K.J., 2003. The first identification of azaspiracids in shellfish from France and Spain. Toxicon 42, 105108.

Marchetti, J., Bougaran, G., Le Dean, L., Mégrier, C., Lukomska, E., Kaas, R., Olivo, E., Baron, R., Robert, R., Cadoret, J.P., 2012. Optimizing conditions for the continuous culture of Isochrysis affinis galbana relevant to commercial hatcheries. Aquacult. 326329, 106-115.

McCarron, P., Kilcoyne, J., Miles, C.O., Hess, P., 2009. Formation of azaspiracids-3, -4, -6, and -9 via decarboxylation of carboxyazaspiracid metabolites from shellfish. J. Agric. Food. Chem. 57, 160-169.

McMahon, T., Silke, J., 1996. West coast of Ireland winter toxicity of unknown aetiology in mussels. Harmful Algae News 14, 2.

Nicolaou, K.C., Chen, D.Y.K., Li, Y.W., Uesaka, N., Petrovic, G., Koftis, T.V., Bernal, F., Frederick, M.O., Govindasamy, M., Ling, T.T., Pihko, P.M., Tang, W.J., Vyskocil, S., 2006. Total synthesis and structural elucidation of azaspiracid-1. Synthesis-based analysis of originally proposed structures and indication of their non-identity to the natural product. J. Am. Chem. Soc. 128, 2258-2267.

Novaczek, I., Madhyastha, M.S., Ablett, R.F., Johnson, G., Nijjar, M.S., Sims, D.E., 1991. Uptake, disposition and depuration of domoic acid by blue mussels (Mytilus edulis). Aquat. Toxicol. 21, 103-118.

O'Driscoll, D., Skrabakova, Z., O'Halloran, J., van Pelt, F., James, K.J., 2011. Mussels increase xenobiotic (Azaspiracid) toxicity using a unique bioconversion mechanism. Environ. Sci. Technol. 45, 3102-3108.

Ofuji, K., Satake, M., McMahon, T., Silke, J., James, K.J., Naoki, H., Oshima, Y., Yasumoto, T., 1999. Two analogs of azaspiracid isolated from mussels, Mytilus edulis, involved in human intoxication in Ireland. Nat. Toxins 7, 99-102.

Perez, R.A., Rehmann, N., Crain, S., LeBlanc, P., Craft, C., MacKinnon, S., Reeves, K., Burton, I.W., Walter, J.A., Hess, P., Quilliam, M.A., Melanson, J.E., 2010. The preparation of certified calibration solutions for azaspiracid-1,-2, and-3, potent marine biotoxins found in shellfish. Anal. Bioanal. Chem. 398, 2243-2252.

Plakas, S.M., El Said, K.R., Jester, E.L.E., Granade, H.R., Musser, S.M., Dickey, R.W., 2002. Confirmation of brevetoxin metabolism in the Eastern oyster (Crassostrea virginica) by controlled exposures to pure toxins and to Karenia brevis cultures. Toxicon 40, 721-729.

Potvin, E., Jeong, H.J., Kang, N.S., Tillmann, U., Krock, B., 2012. First report of the photosynthetic dinoflagellate genus Azadinium in the Pacific Ocean: morphology and molecular characterization of Azadinium cf. poporum. J. Eukaryot. Microbiol. 59, 145156.

Rehmann, N., Hess, P., Quilliam, M.A., 2008. Discovery of new analogs of the marine biotoxin azaspiracid in blue mussels (Mytilus edulis) by ultra-performance liquid chromatography/tandem mass spectrometry. Rapid Commun. Mass Spectrom. 22, 549-558.

Rundberget, T., Gustad, E., Samdal, I.A., Sandvik, M., Miles, C.O., 2009. A convenient and cost-effective method for monitoring marine algal toxins with passive samplers. Toxicon 53, 543-550.

Salas, R., Tillmann, U., John, U., Kilcoyne, J., Burson, A., Cantwell, C., Hess, P., Jauffrais, T., Silke, J., 2011. The role of Azadinium spinosum (Dinophyceae) in the production of azaspiracid shellfish poisoning in mussels. Harmful Algae 10, 774-783. 
Satake, M., Ofuji, K., Naoki, H., James, K.J., Furey, A., McMahon, T., Silke, J., Yasumoto, T., 1998. Azaspiracid, a new marine toxin having unique spiro ring assemblies, isolated from Irish mussels, Mytilus edulis. J. Am. Chem. Soc. 120, 9967-9968.

Taleb, H., Vale, P., Amanhir, R., Benhadouch, A., Sagou, R., Chafik, A., 2006. First detection of azaspiracids in mussels in north west Africa. J. Shellfish Res. 25, 1067-1070.

Tillmann, U., Elbrachter, M., John, U., Krock, B., 2011. A new non-toxic species in the dinoflagellate genus Azadinium: A. poporum sp. nov. Eur. J. Phycol. 46, 74-87.

Tillmann, U., Elbrachter, M., John, U., Krock, B., Cembella, A., 2010. Azadinium obesum (Dinophyceae), a new nontoxic species in the genus that can produce azaspiracid toxins. Phycologia 49, 169-182.

Tillmann, U., Elbrachter, M., Krock, B., John, U., Cembella, A., 2009. Azadinium spinosum gen. et sp. nov. (Dinophyceae) identified as a primary producer of azaspiracid toxins. Eur. J. Phycol. 44, 63-79.

Tillmann, U., Salas, R., Gottschling, M., Krock, B., O'Driscoll, D., Elbrächter, M., 2012. Amphidoma languida sp. nov. (Dinophyceae) reveals a close relationship between Amphidoma and Azadinium. Protist 163, 701-719.

Twiner, M.J., Rehmann, N., Hess, P., Doucette, G.J., 2008. Azaspiracid shellfish poisoning: a review on the chemistry, ecology, and toxicology with an emphasis on human health impacts. Mar. Drugs 6, 39-72.

Ueoka, R., Ito, A., Izumikawa, M., Maeda, S., Takagi, M., Shin-Ya, K., Yoshida, M., van Soest, R.W.M., Matsunaga, S., 2009. Isolation of azaspiracid-2 from a marine sponge Echinoclathria sp. as a potent cytotoxin. Toxicon 53, 680-684.

Villar-Gonzalez, A., Luisa Rodriguez-Velasco, M., Gago-Martinez, A., 2011. Determination of lipophilic toxins by LC/MS/MS: single-laboratory validation. J. AOAC Int. 94, 909-922. 


\section{Tables}

Table 1. Experimental conditions to which mussels were exposed for $24 \mathrm{~h}$.

\begin{tabular}{|c|c|c|c|c|c|}
\hline \multirow[b]{2}{*}{ Treatment $^{\mathrm{a}}$} & \multicolumn{3}{|c|}{ Algae } & \multirow{2}{*}{$\begin{array}{c}\text { AZAs extract } \\
\text { Vol (mL) }\end{array}$} & \multirow{2}{*}{$\begin{array}{l}\text { Total AZAs } \\
\text { Conc (ug/L) }\end{array}$} \\
\hline & Species & Form & Cell/mL & & \\
\hline 1 & - & - & 0 & 0.541 & 7.5 \\
\hline 2 & - & - & 0 & 0.054 & 0.75 \\
\hline 3 & $\mathrm{~T}-I s o$ & Live & $1 \times 10^{6}$ & 0.541 & 7.5 \\
\hline 4 & A. spinosum & Live & $1 \times 10^{5}$ & - & 7.5 \\
\hline 5 & A. spinosum & Lysed & $1 \times 10^{5}$ & - & 7.5 \\
\hline 6 & A. spinosum & Live & $1 \times 10^{4}$ & - & 0.75 \\
\hline 7 & A. spinosum & Lysed & $1 \times 10^{4}$ & - & 0.75 \\
\hline 8 (control) & - & - & 0 & $-{ }^{c}$ & 0 \\
\hline
\end{tabular}

${ }^{a}$ treatment in triplicate, ${ }^{b} \mathrm{AZA} 1+\mathrm{AZA} 2$ (76:24). ${ }^{\mathrm{c}} 0.541 \mathrm{~mL} \mathrm{MeOH}$ was added 
Table 2. AZA metabolite composition (\%) for each tissue sample, ${ }^{a}$ and total AZA concentrations ${ }^{\mathrm{b}}$ in mussel tissues $\left(\mu \mathrm{g} \cdot \mathrm{kg}^{-1}\right)$

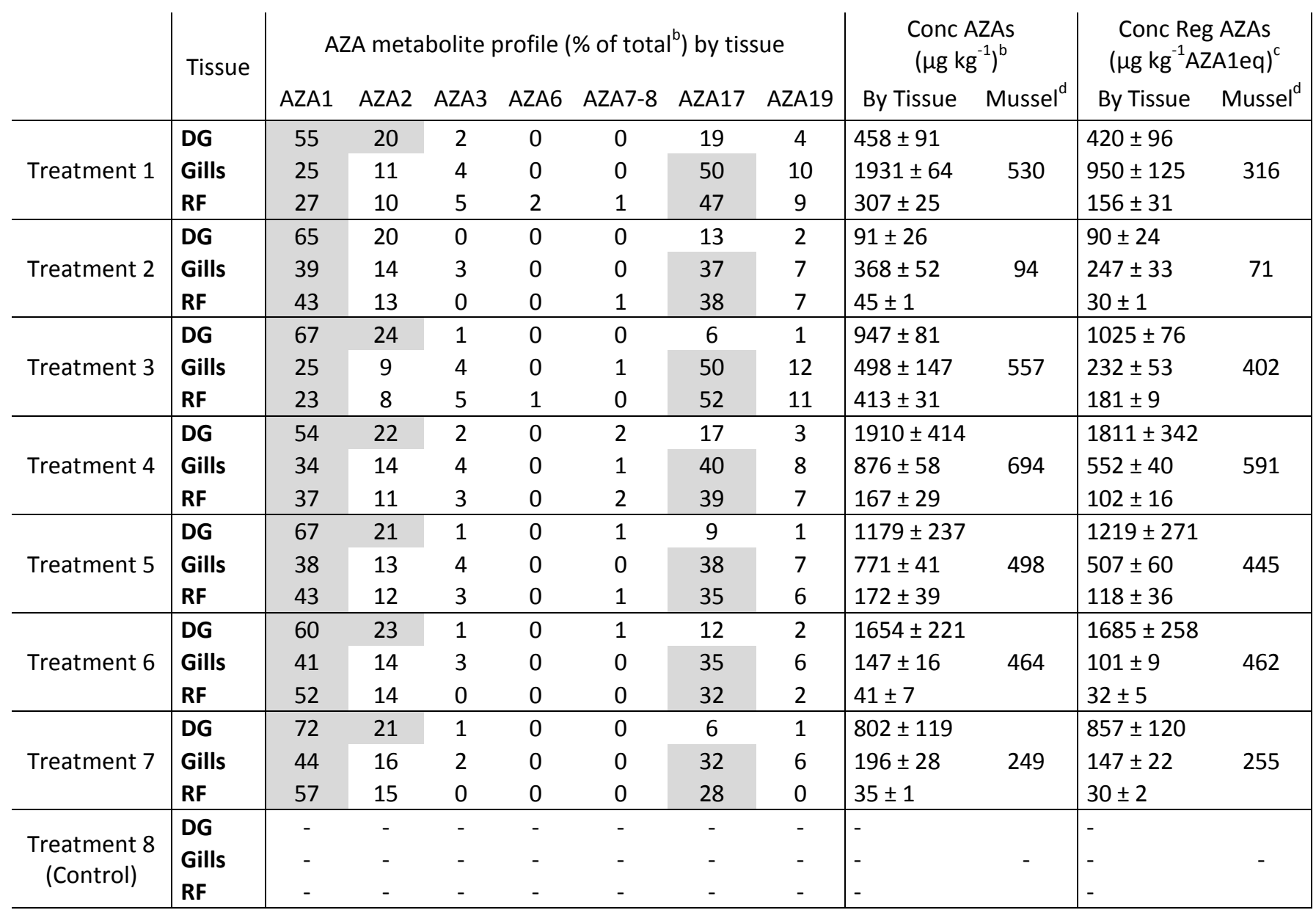

${ }^{a}$ Major metabolites $(\geq 20 \%$ ) are highlighted in grey; $D G=$ Digestive gland, $R F=$ remaining flesh .

${ }^{\mathrm{b}}$ Total $\mathrm{AZAs}=\mathrm{AZA1}+\mathrm{AZA2}+\mathrm{AZA} 3+\mathrm{AZA6}+\mathrm{AZA7}+\mathrm{AZA} 8+\mathrm{AZA17}+\mathrm{AZA19}$

${ }^{\mathrm{c}}$ Regulated $A Z A s=A Z A 1+(A Z A 2 \times 1.8)+(A Z A 3 \times 1.4)$

${ }^{\mathrm{d} C}$ Calculated from the tissue concentrations by assuming a mussel composition of $25.5 \%$ DG, $11.7 \%$ gills, and $62.8 \%$ remaining flesh, by weight 
Table 3. AZA budget after exposure of mussels to semi-purified AZA1

\begin{tabular}{|c|c|c|c|c|c|}
\hline & \multicolumn{4}{|c|}{ Amount $(\mu \mathrm{g})$} & \multirow{2}{*}{$\begin{array}{c}\text { Recovery }^{\mathbf{b}} \\
(\%)\end{array}$} \\
\hline & AZA1 & AZA17 & AZA3 & Total AZAs ${ }^{\mathrm{a}}$ & \\
\hline Dissolved AZA (day 0) & 98.4 & - & - & 98.4 & 100 \\
\hline Dissolved AZA (day 1) & 55.1 & 1.0 & 1.1 & 57.2 & 58.1 \\
\hline Dissolved AZA (day 2.5) & 37.8 & 1.7 & 1.7 & 41.2 & 41.9 \\
\hline Dissolved AZA (day 4) & 26.3 & 2.3 & 2.0 & 30.6 & 31.1 \\
\hline Mussels (day 4) & 10.3 & 16.8 & 1.6 & 28.7 & 29.2 \\
\hline Total recovered & 36.6 & 19.1 & 3.6 & 59.3 & 60.3 \\
\hline \multicolumn{6}{|c|}{${ }^{\mathrm{a}}$ Total AZAs $=\mathrm{AZA} 1+\mathrm{AZA} 3+\mathrm{AZA} 17$} \\
\hline${ }^{\mathrm{b}}$ Recovery $(\%)=($ Total & / AZA1 & y0)) $x$ & & & \\
\hline
\end{tabular}




\section{Figures}

Figure 1. Concentration of T-Iso (Treatment $3(\bullet)$ ) and A. spinosum (Treatments $4(\cdot)$ and $6(4))$ during the experiment with mussels $(n=3)$.

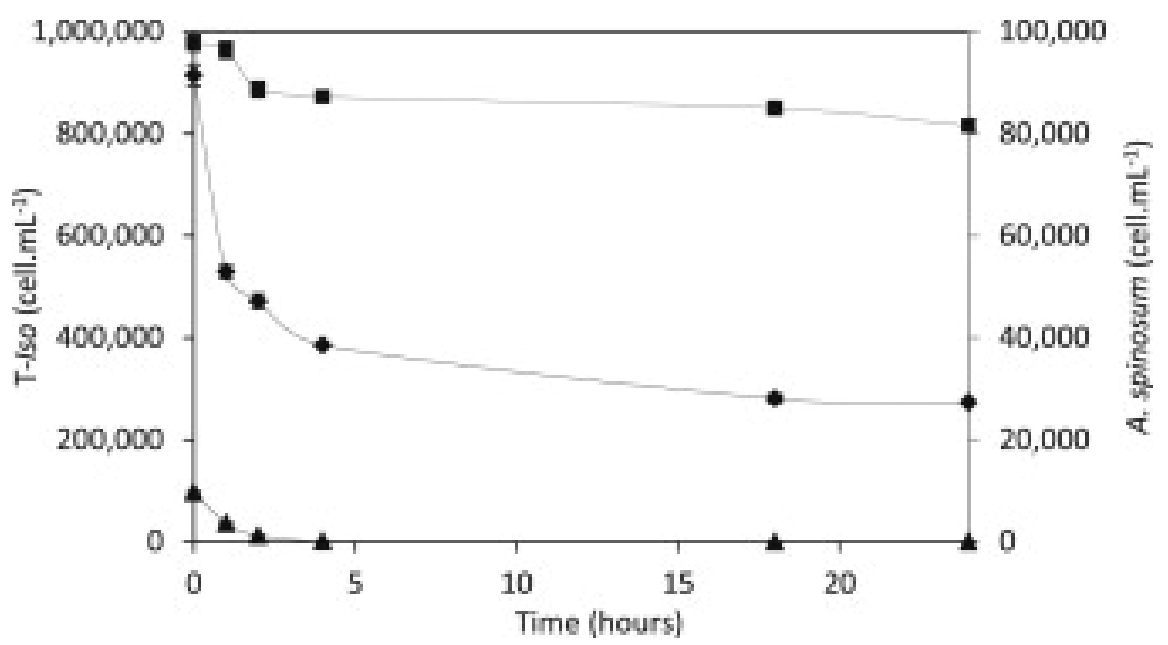


Figure 2. Total AZA tissue distribution in mussels (digestive gland (DG, $\square$ ), remaining flesh (RF, $\square$ ) and gills $(\square)$ ) after $24 \mathrm{~h}$ of exposure to dissolved AZAs, live $A$. spinosum or lysed $A$. spinosum at different concentrations.
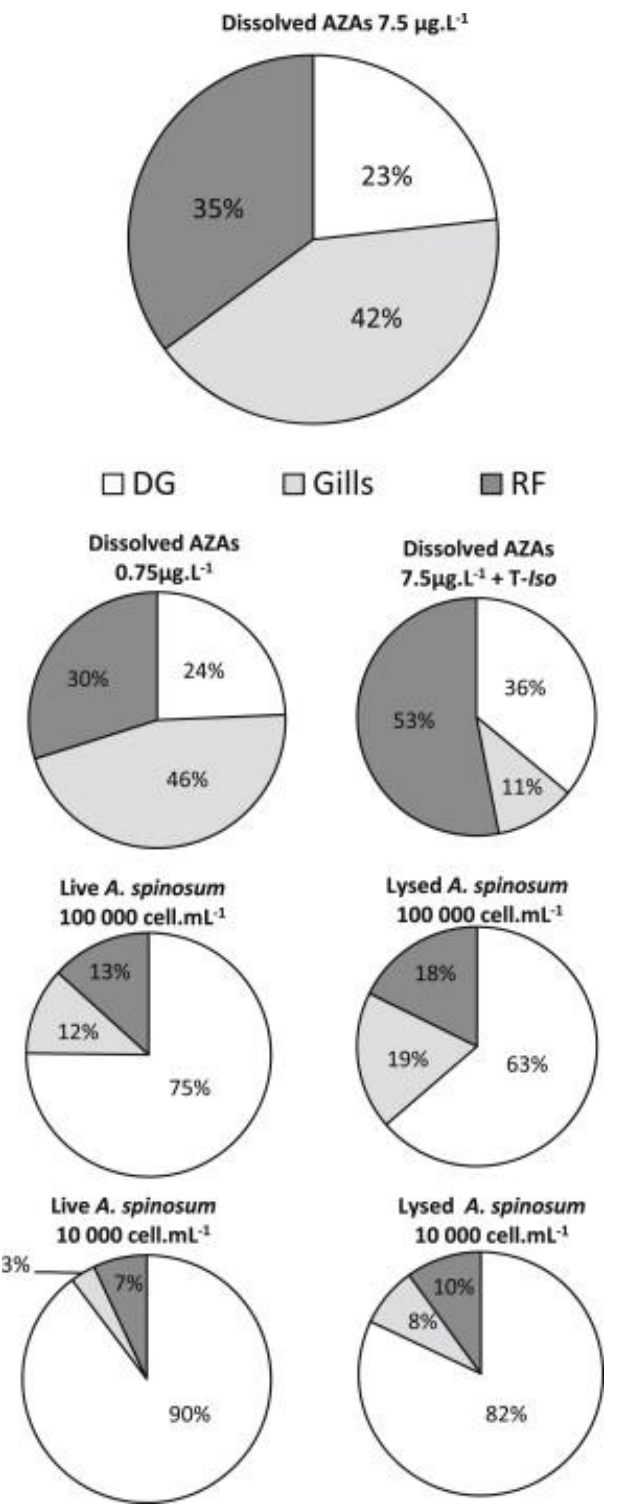
Figure 3. Comparison of metabolites profiles in mussel tissues after exposure to the different conditions by LC-MS/MS analysis (method A): (a) Digestive glands (DG), (b) Gills, and (c) Remaining flesh (RF) after mussel exposure to dissolved AZAs $\left(7.5 \mu \mathrm{g} \mathrm{mL}^{-1}\right)$ (Condition 1); and (d) DG, (e) Gills, and (f) RF after mussel exposure to live $A$. spinosum cells $\left(1 \times 10^{5}\right.$ cell $\left.\mathrm{mL}^{-1}\right)($ Condition 4$)$.
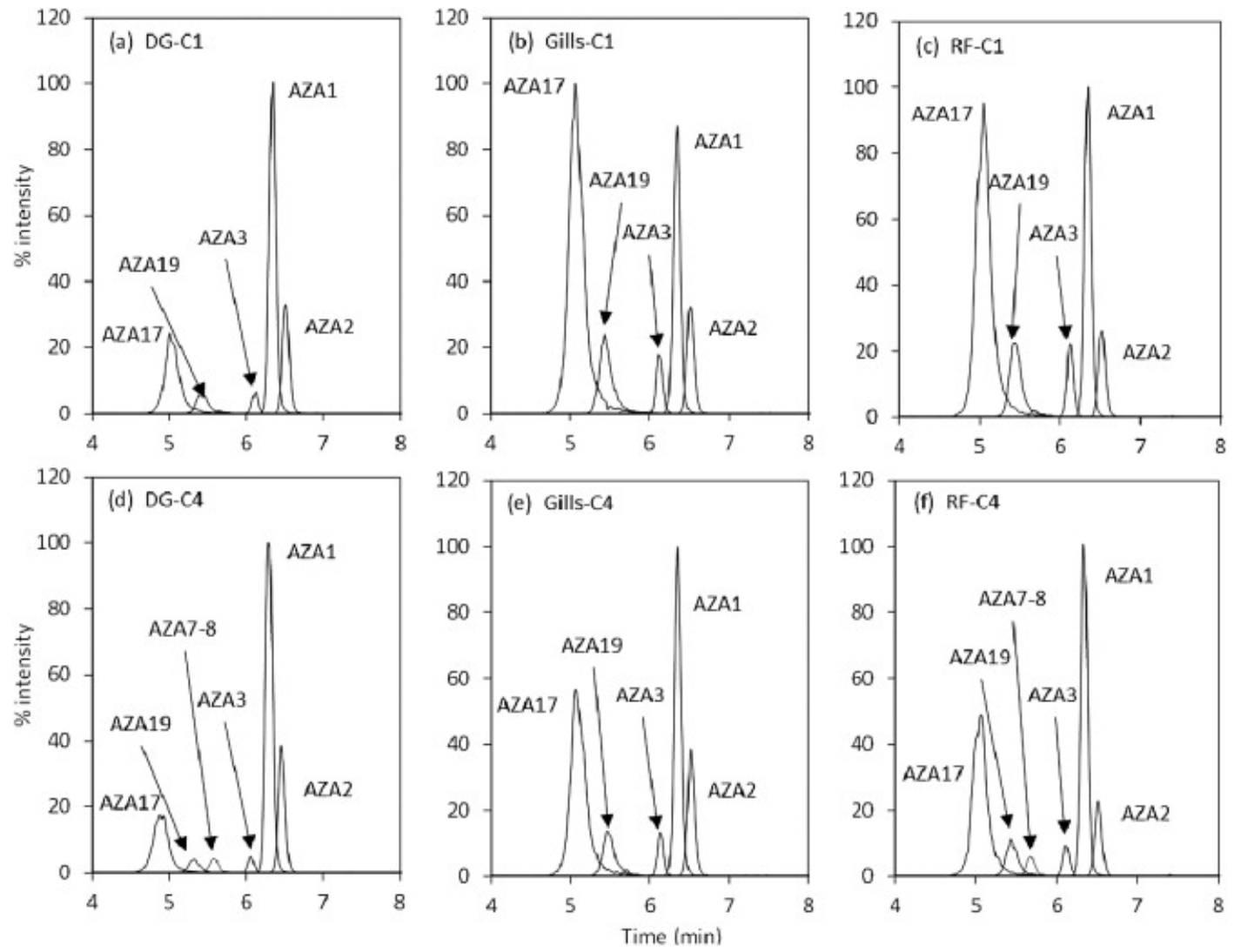

Figure 4. Azaspiracid (AZA) structures and mass-to-charge ratios $(\mathrm{m} / \mathrm{z})$ for the molecular ions $[\mathrm{M}+\mathrm{H}]^{+}$detected in $A$. spinosum and in mussels ( $M$. edulis). Toxins found in $A$. spinosum are shown in bold text.

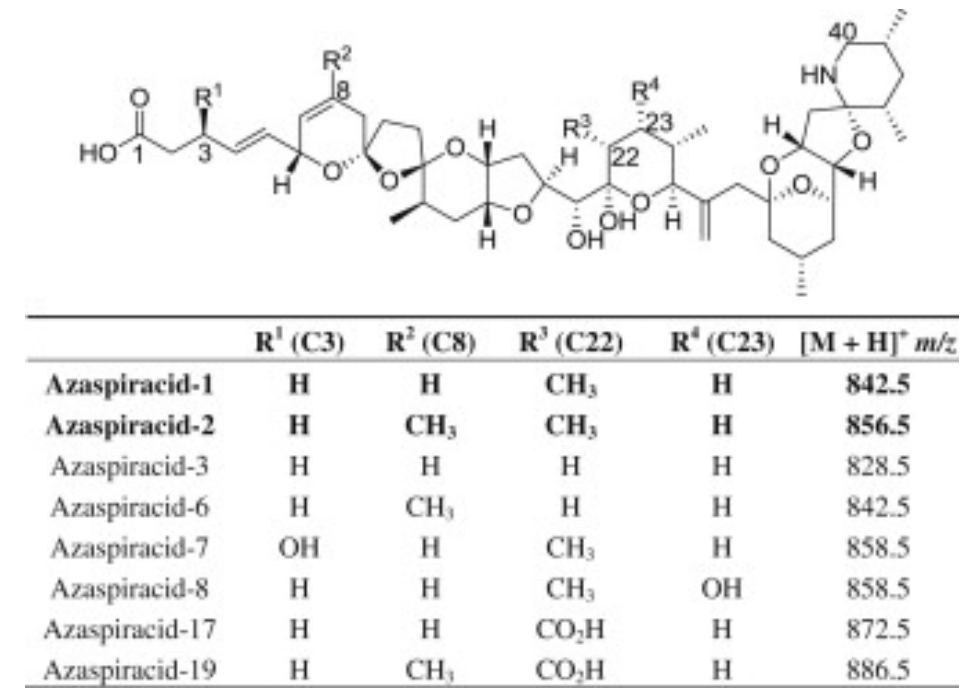

